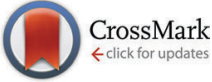

Cite this: Phys. Chem. Chem. Phys., 2017, 19, 1458

Received 3rd October 2016 Accepted 24th November 2016 DOI: $10.1039 / c 6 c p 06765 d$

www.rsc.org/pccp

\title{
Decreasing amyloid toxicity through an increased rate of aggregation $\dagger$
}

\author{
Silvia Sonzini, Helen F. Stanyon and Oren A. Scherman*
}

\begin{abstract}
Amyloid $\beta$ is one of the peptides involved in the onset of Alzheimer's disease, yet the structure of the toxic species and its underlying mechanism remain elusive on account of the dynamic nature of the $A \beta$ oligomerisation process. While it has been reported that incubation of Amyloid $\beta(1-42)$ sequences (A 342 ) lead to formation of aggregates that vary in morphology and toxicity, we demonstrate that addition of a discrete macrocyclic host molecule, cucurbit[8]uril (CB[8]), substantially reduces toxicity in the neuronal cell line SH-SY5Y. The macrocycle preferentially targets Phe residues in A $\beta 42$ complexing them in a 2:1 fashion in neighboring peptide strands. A small but significant structural 'switch' occurs, which induces an increased aggregation rate, suggesting a different cell-uptake mechanism for Aß42 in the presence of $\mathrm{CB}[8]$. Dramatically increasing the rate of $A \beta 42$ aggregation with $\mathrm{CB}[8]$ bypasses the toxic, oligomeric state offering an alternative approach to counter Alzheimer's disease.
\end{abstract}

\section{Introduction}

The onset of Alzheimer's disease involves the over-expression of two pathological amyloid proteins, namely, Amyloid $\beta$ (A $\beta)$, found in vivo both as soluble oligomers and as fibrillar deposits in senile plaques, and hyperphosphorylated tau aggregates, observed in neurofibrillar tangles. ${ }^{1,2} \mathrm{~A} \beta$ varies in length from 39 to 43 amino acid residues (Fig. 1a) and arises from $\beta$ - and $\gamma$-secretase enzymatic cleavage of the amyloid precursor protein. ${ }^{3}$ Amyloid $\beta_{1-40}(\mathrm{~A} \beta 40)$ and Amyloid $\beta_{1-42}(\mathrm{~A} \beta 42)$ are considered major hallmarks of Alzheimer's disease, the latter being more prone to aggregation and generally more toxic. ${ }^{1,4,5}$ Disease progression is related to misfolding and aggregation of the peptide fragment into oligomers with $\beta$-arch structural motifs. (Fig. 1b) ${ }^{6}$

It has been reported that $A \beta$ oligomers of different size and morphology, such as dimers, ${ }^{7,8}$ tetramers, ${ }^{9,10}$ pentamers, ${ }^{4}$ dodecamers $^{11}$ and $\mathrm{A} \beta$-derived diffusible ligands ${ }^{12}$ are connected to neuronal impairment. Nevertheless, as the soluble oligomeric aggregates are in constant equilibrium with each other, determining both their structure and their mechanism of interaction with neuronal cells has remained elusive. It has been suggested that elevated toxicity of small, soluble oligomers compared to mature fibres may be related to their higher diffusion through tissues and into various cellular compartments, ${ }^{2,13}$ enabling both receptor-mediated and non-receptor-mediated membrane

Melville Laboratory for Polymer Synthesis, Department of Chemistry, University of Cambridge, Lensfield Road, Cambridge CB2 1EW, UK. E-mail: oas23@cam.ac.uk

$\dagger$ Electronic supplementary information (ESI) available. See DOI: 10.1039/c6cp06765d. The data supporting the publication can be accessed at https://doi.org/10.17863/ CAM.6653. a

DAEFRHDSGYEVHHQKLVFFAEDVGSNKGAIIGLMVGGVVIA

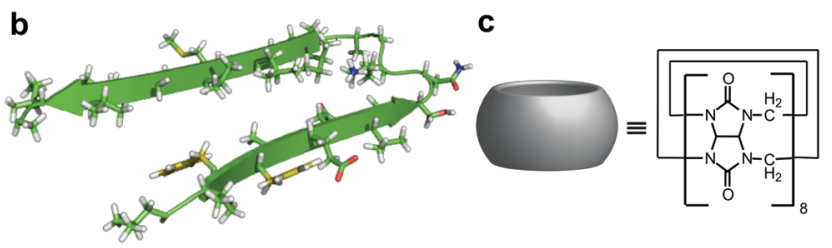

Fig. $1 \quad A \beta 42$ and $C B[8]$ structure and analyses of their binding interactions. (a) $A \beta 42$ sequence, one letter code. (b) Model representation of $A \beta 42$ hairpin produced from PDB 2BEG6. (c) $\mathrm{CB}[8]$ cartoon and molecular formula.

interactions. Furthermore, the lower toxicity of amyloid fibrils suggests that many of the toxic structural elements are inaccessible in the fibre core. ${ }^{2,13}$ The higher toxicity of oligomers over fibres was recently corroborated by Cohen et al., whereby a chaperone was shown to inhibit the formation of small aggregates and redirect the aggregation pathway towards fibre formation, thus decreasing $\mathrm{A} \beta 42$ toxicity both in vitro and in vivo. ${ }^{14}$

Herein we exploited the reduction of the oligomers by significantly increasing the rate of $A \beta$ aggregation through specifically targeting its aromatic residues, thus dramatically reducing the toxicity of the peptide. This concept has only been investigated with a few small molecules and a large dendrimer system able to increase $A \beta$ aggregation by non-specific $\pi$-stacking interactions, ${ }^{15-18}$ but the use of a macrocycle explicitly binding at the aromatic residues has never been exploited before. Therefore, we investigated the oligomeric nature of $A \beta 42$ in the presence of the eight-membered macrocyclic host molecule cucurbit[8]uril (CB[8], Fig. 1c) and evaluated its toxicity compared to wild type 
(WT) aggregates. Cucurbituril macrocyclic hosts form stable inclusion complexes in aqueous media and are non-cytotoxic; ${ }^{19,20}$ interactions between $\mathrm{CB}[8]$ and aromatic amino acid residues have been widely investigated, ${ }^{21-27}$ especially Phe and Trp, with several recent biochemical applications. ${ }^{28-30}$ Recently, Kim et al. ${ }^{29}$ reported the decrease in aggregation rate of both $A \beta 40$ and $A \beta 42$ in the presence of high concentrations of $\mathrm{CB}[7]$, probably on account of the interaction between the macrocycle and the Phe residues in the sequence. Conversely, we focused on $\mathrm{CB}$ [8], which is unique in that it is capable of binding two aromatic residues simultaneously in its larger cavity. ${ }^{23,24}$

Aggregates of the $\mathrm{A} \beta 42 \cdot \mathrm{CB}[8]$ complexes exhibited similar features to those of the WT, however, they formed much faster and grew much larger in size. $\mathrm{CB}[8]$ thus catalyses fast aggregation of the peptide strands surpassing the soluble oligomeric stage, and leads to significantly lower toxicity compared to WT aggregates.

To the best of our knowledge, this is the first report whereby a macrocycle able to specifically target the aromatic residues was employed to induce, rather than inhibit, $A \beta 42$ aggregation in order to decrease its toxicity; we expect our results will give rise to alternative approaches to counter Alzheimer's disease.

\section{Experimental section}

\section{Peptide synthesis and characterisation}

$\mathrm{A} \beta 42$ and $\mathrm{A} \beta 42 \mathrm{~A}_{4,19,20}$ were prepared on a Liberty automated microwave solid-phase peptide synthesiser (CEM) using a Fmocbased synthetic strategy. ${ }^{31}$ The $\varepsilon$-aminohexanoic acid (Ahx, Novabiochem) and fluoresceinisothiocyanate (FITC, Sigma-Aldrich) were then added on a portion of both $\mathrm{A} \beta 42$ resins manually; a 5 eq. solution of Ahx/diisopropylcarbodiimide (DIC)/hydroxybenzotriazole (HOBt) was added using a double-coupling strategy and $12 \mathrm{~h}$ reaction time, followed by washing and deprotection of the resin with $20 \%$ piperidine in dimethylformamide (DMF) (3 times, $3 \mathrm{~min}$ each), then a 5 eq. solution of FITC/diisopropylethylamine (DIPEA) 1:2 was added and double-coupled for $12 \mathrm{~h}$. To avoid Met oxidation, the cleavage cocktail used to detach the peptides from the resin was reagent $\mathrm{H}$ (trifluoroacetic acid (TFA)/thioanisole/ phenol/water/ethandithiol/dimethylsulfide/ $\left.\mathrm{NH}_{4} \mathrm{I}\right) .{ }^{32}$ After ether precipitation the peptides were stored at $-20{ }^{\circ} \mathrm{C}$. The purity of all peptides was assessed by analytical High Pressure Liquid Chromatography (HPLC) (Varian 940-LC) and Electron Spray Ionisation-Mass Spectrometry (ESI-MS, LTQ-Velos), as reported in Fig. S1 and S2 (ESI $\dagger$ ). Analytical HPLC was performed using a gradient of acetonitrile from $25 \%$ to $90 \%$ in $\mathrm{mQ}$ water with $0.1 \%$ TFA over $17 \mathrm{~min}$ ( 2 min pre-run and $15 \mathrm{~min}$ actual run). The column used was a VariTide RPC (Agilent) column $4.6 \times$ $250 \mathrm{~mm}$, with 200 A pore size and $6 \mu \mathrm{m}$ particles. The peptides were dissolved in 1,1,1,3,3,3-hexafluoro-2-propanol (HFIP, Sigma-Aldrich) and sonicated for $2 \mathrm{~min}$; HFIP was then removed by nitrogen stream and the resulting dry film stored at $-20{ }^{\circ} \mathrm{C}$ before use. ${ }^{33}$ The monomerisation of the peptides was ensured by dissolution in $60 \mathrm{mM} \mathrm{NaOH}\left(1 \mathrm{mg} \mathrm{mL}^{-1}\right)$ and then sonicated for $15 \mathrm{~min}$ in an ice cold water bath. The resulting solution was passed through a $0.22 \mu \mathrm{m}$ filter (Millipore) and then through a
$10 \mathrm{KDa}$ cut-off Amicon centrifugal filter (Merck Millipore), the concentration was assessed by UV-Vis. ${ }^{34}$ Monomerised peptides were kept on ice and used within $3 \mathrm{~h}$. Unless otherwise stated, the samples were then diluted to the desired concentration using $0.2 \mu \mathrm{m}$ (Millipore) freshly-filtered $10 \mathrm{mM}$ phosphate buffer (PB), $\mathrm{pH} 7.4$ in the presence or absence of $\mathrm{CB}[8]$ at different concentrations and directly measured at time $0 \mathrm{~h}$. Each sample was then incubated at $37{ }^{\circ} \mathrm{C}$ with constant rotation (200 rpm) in a shaker incubator (INFORS HT Multitiron II), data were collected every hour until the signal started to decrease on account of peptide precipitation. For transmission electron and atomic force microscopy experiments the samples were incubated at $37{ }^{\circ} \mathrm{C}$ with constant rotation $(250 \mathrm{rpm})$ on a Grant Microtube thermo shaker supplied with PSC15 block (Thermo-Fisher).

\section{Isothermal titration calorimetry (ITC)}

To evaluate the binding between the peptides and CBs an ITC-200 (Microcal) was used. A $0.2 \mu \mathrm{m}$ (Millipore) filtered $\mathrm{CB}[8](80 \mu \mathrm{M})$ or $\mathrm{CB}[7](230 \mu \mathrm{M})$ solution was titrated into a freshly prepared peptide $(5 \mu \mathrm{M})$ solution in $10 \mathrm{mM} \mathrm{PB}, \mathrm{pH}$ 7.4. The data were collected at $25{ }^{\circ} \mathrm{C}$. After subtracting the blank injection $(\mathrm{CB}[8]$ or $\mathrm{CB}[7]$ into buffer) values, the data obtained were analysed using Origin software. Each ITC experiment was repeated with three independently prepared samples.

\section{Thioflavin $\mathrm{T}(\mathrm{ThT})$ assay}

The ThT assay was carried out to follow the aggregation of $\mathrm{A} \beta 42$ in the presence and in the absence of $\mathrm{CB}[8]$; ThT emission was recorded by fluorimeter (Cary Eclipse). The excitation was applied at $450 \mathrm{~nm}$ and the emission collected at $495 \mathrm{~nm}$, the temperature was kept at $25{ }^{\circ} \mathrm{C}$. For each data point, a $50 \mu \mathrm{L}$ aliquot of each sample was added to $750 \mu \mathrm{L}$ of $0.2 \mu \mathrm{m}$ (Millipore) freshlyfiltered ThT solution ( $90 \mu \mathrm{M}$ in PB $10 \mathrm{mM}, \mathrm{pH}$ 7.4, Sigma-Aldrich) and the emission collected. The blank emission of ThT in the stated conditions at $495 \mathrm{~nm}$ was subtracted and the values normalised to the highest value obtained within the set of experiments. The data are reported as mean $\pm \mathrm{SD}$ of three independent samples. The fitting is reported in the $\mathrm{ESI} \dagger$ (see Tables). ${ }^{35}$

\section{Circular dichroism (CD)}

The transition from a disordered to a $\beta$-sheet conformation of $\mathrm{A} \beta 42$ in the presence and in the absence of $\mathrm{CB}[8]$ was followed by far-UV CD on a Chirascan spectrometer (Applied Photophysics). The data were collected from 250 to $195 \mathrm{~nm}$, using $0.5 \mathrm{~nm}$ steps, $1 \mathrm{~nm}$ bandwidth, an acquisition time of $1 \mathrm{~s}$ and collecting 3 repeats for each sample to minimise the noise, the temperature was kept at $25^{\circ} \mathrm{C}$. Each solution was analysed as three independent samples and smoothed with a factor of 8 , the background subtracted and the data averaged.

\section{Transmission electronic microscopy (TEM)}

The fibrils obtained from $\mathrm{A} \beta 42$ in the presence and in the absence of $\mathrm{CB}[8]$ were recorded by TEM imaging (FEI Philips Tecnai 20). Samples were prepared depositing a $8 \mu \mathrm{L}$ drop solution at different aggregation times on $\mathrm{C} 300 \mathrm{Cu}$ (carbon film on 300 mesh copper) grids (EMResolutions), followed by one 
water wash and staining using $2 \% \mathrm{w} / \mathrm{v}$ phosphotungstic acid (PTA) aqueous solution.

\section{Atomic force microscopy (AFM)}

The fibrils obtained from $A \beta 42$ in presence and absence of $\mathrm{CB}[8]$ were recorded by AFM imaging (Agilent 5500 AFM) using tapping in air mode to further evaluate their morphology. Samples were prepared depositing a $10 \mu \mathrm{L}$ drop solution after 6 days of incubation on a mica surface (Agar Scientific) approximately $0.5 \mathrm{~cm} \times 1 \mathrm{~cm}$. The surfaces had been previously cleaved in order to remove any extraneous organic matter. The solutions were allowed to remain on the freshly cleaved mica surfaces for $5 \mathrm{~min}$ before washing with $\mathrm{mQ}$ water $(0.6 \mathrm{~mL})$ and allowed to dry in air for at least $30 \mathrm{~min}$. OTESPA-R3 cantilevers (Bruker AFM probes) with a resonant frequency of approx. $314 \mathrm{kHz}$, tip radius of $7 \mathrm{~nm}$ and spring constant $26 \mathrm{~N} \mathrm{~m}^{-1}$ were used. Images were taken over an area of approximately $2 \mu \mathrm{m}^{2}$ at a rate of 1.02 lines per $\mathrm{s}$ with a resolution of $512 \times 512$ pixels. During measurements the topographic trace in both trace and retrace mode, amplitude and phase were all recorded.

\section{Dynamic light scattering (DLS)}

The aggregation profile of $\mathrm{A} \beta 42$ in the presence and in the absence of $\mathrm{CB}[8]$ was followed by DLS (Malvern Zetasizer Nano ZS) and the scattered laser light intensities measured at $173^{\circ}$ angles, the temperature was set at $25{ }^{\circ} \mathrm{C}$. The data are reported as the mean of three independent samples.

\section{Cell viability assay}

A neuroblastoma cell line, SH-SY5Y (maximum passage used 46), was used to evaluate the toxicity of $\mathrm{A} \beta 42$ both in the presence and in the absence of $\mathrm{CB}[8]$ in vitro. SH-SY5Y cells were cultured with Dulbecco's modified Eagle medium (DMEM) supplemented with $10 \%$ fetal bovine serum (FBS) and 1\% Pen-Strep (Life Technologies) and incubated at $37{ }^{\circ} \mathrm{C}$ and $5 \% \mathrm{CO}_{2}$. The cells were plated at a concentration $1 \times 10^{4}$ per well on collagen I coated 96-well plates (Life Technologies) and incubated overnight. The toxicity of $\mathrm{A} \beta 42$ in the absence of $\mathrm{CB}[8]$ was first assessed by treating the cells with media supplemented with different concentrations of A 342 freshly dissolved in $\mathrm{NaOH}(60 \mathrm{mM})$, as reported in the ESI $\dagger$ (Fig. S8). For experiments in the presence of $\mathrm{CB}[8]$, the cell cultures were treated with media containing a fixed concentration of $\mathrm{A} \beta 42(7 \mu \mathrm{M})$, freshly dissolved or incubated as solution in $60 \mathrm{mM} \mathrm{NaOH}$ for $24 \mathrm{~h}$ at $37{ }^{\circ} \mathrm{C}$ with constant rotation (200 rpm) in a shaker incubator (INFORS HT Multitiron II), and different concentrations of $\mathrm{CB}[8]]^{36}$ In both cases, the cells were tested for mitochondrial activity using a standard MTS, 3-(4,5-dimethylthiazol-2-yl)-5-(3-carboxymethoxyphenyl)-2-(4-sulfophenyl)-2 $H^{-}$ tetrazolium, assay kit (CellTiter 96 kit, Promega) after $48 \mathrm{~h}$ incubation time. A solution of $100 \mu \mathrm{L}$ phosphate buffered saline (PBS) and $20 \mu \mathrm{L}$ MTS solution was added to each well and the cells were incubated for $4 \mathrm{~h}$. Cell viability was quantified by measuring the absorbance at $490 \mathrm{~nm}$ using a FLASHScan plate reader (Analytik-Jena). The data were averaged from at least three independent replicates and the results were analysed using two-tailed $t$-test to establish any significance between
$A \beta 42$ alone and in the presence of different concentrations of $\mathrm{CB}[8]$ (see ESI $\dagger$ Tables S2-S4) and the errors are reported as standard deviation at the $95 \%$ confidence interval.

\section{Fluorescence microscopy}

The distribution of FITC-A $\beta 42$ in vitro was imaged by fluorescence microscopy (Leica TCS SP5) equipped with a digital camera (Leica DFC365 FX). Filter cube A and I3 were respectively used for imaging DAPI and FITC emission. Glass-bottom 48-well plates (SLS) were coated with $10 \mu \mathrm{g} \mathrm{cm}^{-2}$ of rat-tail collagen I (SigmaAldrich) and SH-SY5Y cells, cultured as described in the previous section, plated as $3 \times 10^{4}$ cells per well and incubated over night at $37{ }^{\circ} \mathrm{C}$ and $5 \% \mathrm{CO}_{2}$. The cultures were then treated with FITC$\mathrm{A} \beta 42$ freshly dissolved or incubated as solution in $60 \mathrm{mM} \mathrm{NaOH}$ for $24 \mathrm{~h}$ at $37^{\circ} \mathrm{C}$ with constant rotation $(200 \mathrm{rpm})$ in a shaker incubator (INFORS HT Multitiron II) in the presence or in the absence of $\mathrm{CB}[8]$ in the culture media. After a $48 \mathrm{~h}$ incubation time the cells were fixed with $4 \%$ formaldehyde solution in PBS enriched with 4,6-diamidino-2-phenylindole dihydrochloride (DAPI $2 \mu \mathrm{M}$, Sigma-Aldrich) to enable DNA staining.

\section{Results and discussion}

\section{$\mathrm{CB}[8]$ induced folding of $\mathrm{A} \beta 42$ through aromatic residues complexation}

Our previous studies on the dimerisation of $A \beta$ fragments, ${ }^{24}$ encouraged us that $\mathrm{CB}[8]$ would exhibit host-guest interactions with the full-length $\mathrm{A} \beta 42$. We investigated any interaction using ITC, which demonstrated the occurrence of binding events, as shown in Fig. S3a (ESI $\dagger$ ). Fitting sigmoidal curves obtained in the ITC measurements to binding models, however, was elusive suggesting high complexity of the system; nevertheless, valuable information was extracted.

The endothermic peaks for all of the injections (see Fig. S3a, ESI $\dagger$ ), suggested that the binding event is entropically driven correlating to a typical folding and aggregation process observed for proteins with a highly hydrophobic core. ${ }^{3-39}$ Moreover, the ITC data resulted in a binding ratio slightly $\geq 2$ for $\mathrm{CB}[8]: \mathrm{A} \beta 42$, highlighting the presence of several interactions between $\mathrm{CB}[8]$ and the three Phe residues (4, 19 and 20), and possibly $\mathrm{Tyr}_{10}$. We also carried out ITC of $\mathrm{CB}[8]$ with a modified $\mathrm{A} \beta 42$ sequence, which contained Ala instead of Phe residues $\left(A \beta 42 \mathrm{~A}_{4,19,20}\right)$ to support the hypothesis of Phe $\mathrm{CB}[8]$ complexation. This ITC data indicated a binding ratio just above 1, likely on account of an interaction with $\mathrm{Tyr}_{10}{ }^{25}{ }^{25}$ Complexation between $\mathrm{CB}[8]$ and $\mathrm{A} \beta 42 \mathrm{~A}_{4,19,20}$ was noticeably enthalpically driven, suggesting that no aggregation was induced (see Fig. S3b, ESI†). Additionally, ITC of $\mathrm{CB}[7]$, which can only bind a single aromatic residue, with $\mathrm{A} \beta 42$ was carried out. In this case, exothermic peaks were observed, indicating that indeed no folding was induced during the titration, yielding a curve with a binding ratio close to 4 , which corresponds to $1: 1$ binding between $\mathrm{CB}[7]$ and the three Phe residues in positions 4,19 and 20 as well as $\operatorname{Tyr}_{10}$ (see Fig. S3c, ESI $\dagger$ ). We therefore inferred that the molar ratio observed for the $\mathrm{CB}[8]$ titration into the $\mathrm{A} \beta 42$ solution is linked 
to the formation of ternary complexes with Phe residues and a binary complex with Tyr. Importantly, each of the homoternary complexes only account for 0.5 molar equivalents of the complexation observed between $\mathrm{CB}[8]$ and $\mathrm{A} \beta 42$, whereas the binary complex between $\mathrm{Tyr}_{10}$ and $\mathrm{CB}[8]$ accounts for 1 equivalent of $\mathrm{CB}[8]$. Considering all of the experimental evidence, $\mathrm{CB}[8]$ is likely forming homoternary complexes with the 3 Phe residues, bringing neighboring A $\beta 42$ strands into closer proximity and promoting folding during the ITC experiment.

\section{$\mathrm{CB}[8]$ accelerates $\mathrm{A} \beta 42$ aggregation and promotes Phe $\pi-\pi$ stacking}

After establishing clear binding events between $\mathrm{CB}[8]$ and $\mathrm{A} \beta 42$, we investigated the influence of $\mathrm{CB}[8]$ addition on its aggregation. Firstly, we studied the rate of aggregation using the ThT assay, presented in Fig. 2a. Larger CB homologues can bind ThT as it is an aromatic and positively charged molecule, ${ }^{40,41}$ therefore, we performed the assay ex situ in order to avoid any undesired binding of $\mathrm{CB}[8]$ to the dye and minimise noise related to this side interaction. The aggregation curves obtained for $\mathrm{A} \beta 42$ at different concentrations of $\mathrm{CB}[8]$ showed a slightly longer lag
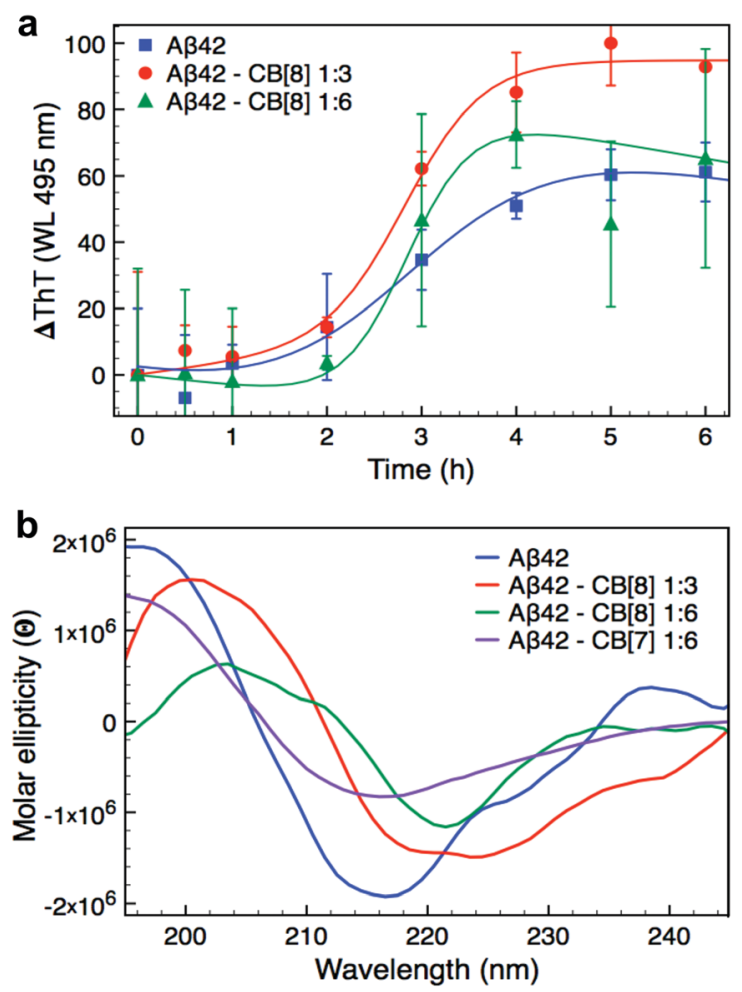

Fig. 2 Aggregation studies on $A \beta 42$ and $C B[8]$ complexes. (a) ThT assay of $A \beta 42(7 \mu M)$ with 0,3 or 6 -fold excess $C B[8]$. The assay was performed ex situ using a final concentration of $90 \mu \mathrm{M}$ ThT; the data reported are the mean $\pm S D$ of three independent samples. (b) $C D$ spectra of $A \beta 42(7 \mu M)$ with 0,3 or 6 -fold excess $C B[8]$ or 6 -fold excess $C B$ [7] after $5 \mathrm{~h}$ of incubation. The $C D$ spectrum for $A \beta 42 \cdot C B[8] 1: 6$ was reported after $3 \mathrm{~h}$ of incubation, since precipitation was observed over longer periods. All the $C D$ spectra are represented as average of three independent samples. All samples used in the ThT and CD assays were dissolved in $10 \mathrm{mM} \mathrm{PB} \mathrm{pH}$ 7.4 and directly measured for time $0 \mathrm{~h}$. The samples were then kept at $37^{\circ} \mathrm{C}$ and shaken at $200 \mathrm{rpm}$ between each measurement. phase in the presence of the macrocycle, but a significantly higher rate of elongation, nearly doubling when a 6-fold excess of $\mathrm{CB}[8]$ was employed (see Table S1, ESI $\dagger$ ). Moreover, the data obtained with a 6-fold excess of $\mathrm{CB}[8]$ were extremely noisy, this was probably related to the very high rate of aggregation.

We further investigated the aggregation of $A \beta 42$ both in the presence and absence of $\mathrm{CB}[8]$ using far-UV $\mathrm{CD}$ to evaluate the change in secondary structure of the peptide (Fig. $2 \mathrm{~b}$ and Fig. S4 in ESI $\dagger$ ). All of the samples exhibited a predominantly disordered conformation upon dissolution with a broad minimum at about $195 \mathrm{~nm}$ (time $0 \mathrm{~h}$, Fig. S4, ESI $\dagger$ ). After only 1 h, A $\beta 42$ incubated with $\mathrm{CB}[8]$ clearly showed bands typical of $\beta$-sheet structure, which were absent for $A \beta 42$ incubated alone. The samples with a 6-fold excess of $\mathrm{CB}[8]$ reached complete folding within $3 \mathrm{~h}$, whilst $\mathrm{A} \beta 42$ samples in the absence of $\mathrm{CB}[8]$ required $5 \mathrm{~h}$ (see Fig. S4, ESI $\dagger$ ). In the presence of $\mathrm{CB}[8]$, both the minimum and maximum of the $\beta$-sheet bands were shifted from 218 and $196 \mathrm{~nm}$ to 220 and $202 \mathrm{~nm}$, respectively (Fig. 2b). This phenomenon has been previously reported, suggesting $n-\pi^{*}$ interactions between side chains in peptides containing several Phe residues in close proximity. ${ }^{42-44}$ The presence of $\mathrm{CB}[8]$ could induce a denser packing of the side chains by simultaneously complexing two Phe residues on neighboring strands. ${ }^{45,46}$ To further explore this structural hypothesis, a far-UV CD experiment was repeated with a 6-fold excess of $\mathrm{CB}[7]$; no red shift was observed (Fig. 2b), corroborating our hypothesis.

\section{$\mathrm{CB}[8]$ increases the size of $\mathrm{A \beta 42}$ aggregates and their rate of formation}

On account of the increase in aggregation rate of $A \beta 42$ in the presence of $\mathrm{CB}[8]$ (ThT assay and time dependent CD measurements), the morphology of the $\mathrm{A} \beta 42 \cdot \mathrm{CB}[8]$ aggregates was investigated. TEM was employed to observe the morphology of the negatively stained aggregates at different time points, as depicted in Fig. 3. Although the fibres formed by $A \beta 42$ and $\mathrm{CB}[8]$ exhibited a more globular shape (Fig. 3, bottom) compared to those obtained from WT A $\beta 42$ (Fig. 3, top), both samples consisted mainly of oligomers after $1 \mathrm{~h}$ of incubation, oligomers and fibres after 5 and $24 \mathrm{~h}$ and only fibres after 7 days. It is important to point out that $\mathrm{CB}[8]$ alone interacts with the commonly employed stain phosphotungstic acid (PTA), leading to the formation of round particles on the TEM grid (see Fig. S5a, ESI $\dagger$ ) similar to the motifs highlighted in the orange circle in Fig. 3. This result suggested that the rounded particles that appear amongst the $\mathrm{A} \beta 42 \cdot \mathrm{CB}[8]$ fibres are likely related to the presence of $\mathrm{CB}[8]$ localised at the solvent exposed surface of the fibrils. Moreover, in order for $\mathrm{CB}[8]$ to interact with the PTA stain and create this globular effect on the TEM grid, one of the two carbonyl-lined portals of $\mathrm{CB}[8]$ must likely remain uncomplexed, ${ }^{47}$ suggesting that the macrocycle might bind both Phe residues from the same portal side. This hypothesis is supported by several other examples that have been reported previously where guests preferentially bind with the macrocycle in a syn conformation ${ }^{48,49}$ and may be dictated by preferential arrangement of the $A \beta 42$ strands in this case.

As fibre morphology can be inherited from parent seeds, ${ }^{50,51}$ we also added a $10 \%$ solution of $\mathrm{A} \beta 42 \cdot \mathrm{CB}[8]$ incubated for $24 \mathrm{~h}$ 

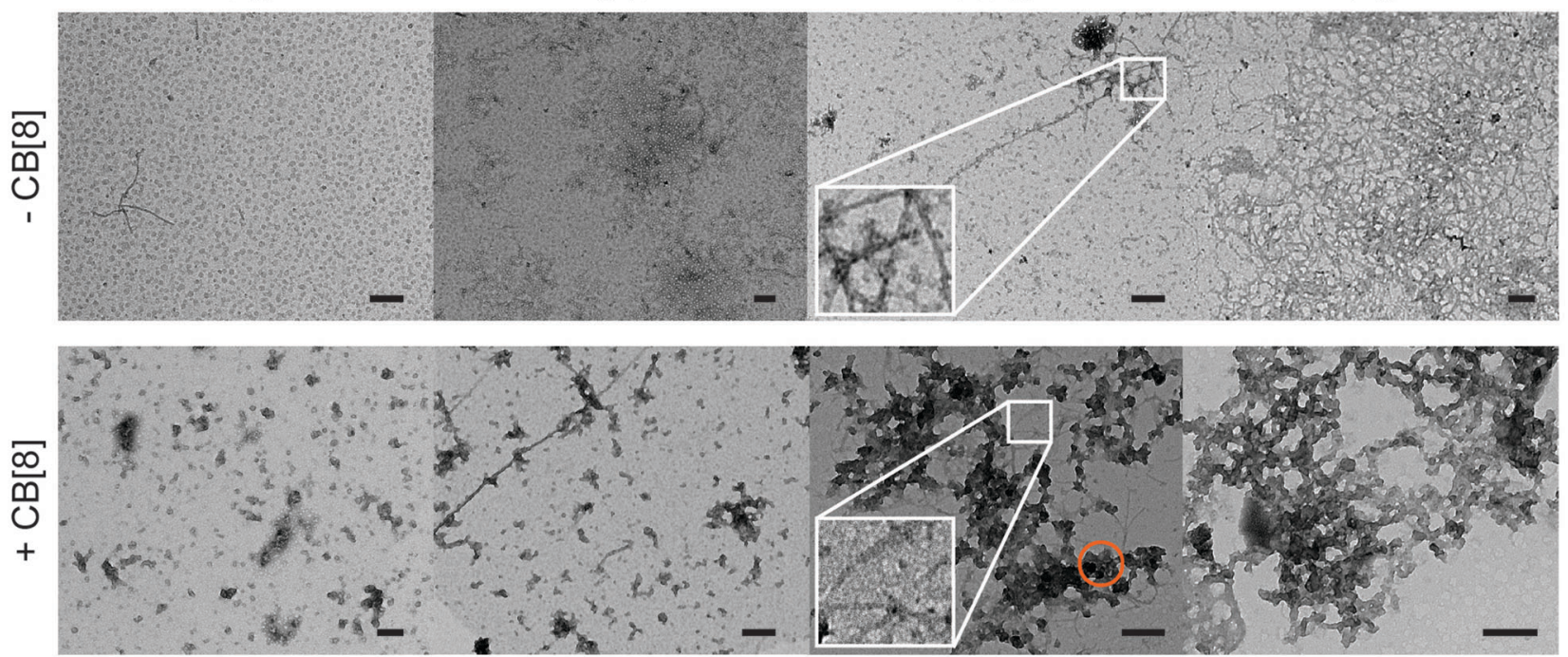

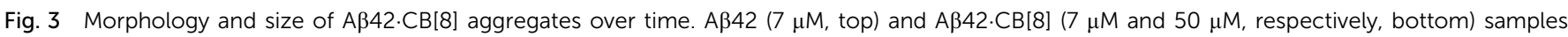
prepared at different times, from left to right: $1 \mathrm{~h}, 5 \mathrm{~h}, 24 \mathrm{~h}, 7$ days. The white boxes at $24 \mathrm{~h}$ represent a 9 -fold enlargement of the main image both for $A \beta 42$ and $A \beta 42 \cdot C B[8]$; the orange circle highlights the presence of globular features in $A \beta 42 \cdot C B[8]$ sample likely stemming from the interactions between

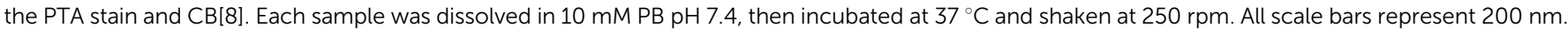

to a fresh $\mathrm{A} \beta 42$ solution and imaged it by TEM after 6 days in order to evaluate any change in $A \beta 42$ aggregation. The fibres obtained indicated WT A 342 features and some of the crosslinks presented a more globular shape, symptomatic of $\mathrm{CB}[8]$ presence (see Fig. S5b, ESI $\dagger$ ), thus the A $\beta 42 \cdot \mathrm{CB}[8]$ complexes are likely behaving as on-pathway aggregates.

In an effort to characterise the fibres formed both in the presence and in the absence of $\mathrm{CB}[8]$ without interference from any staining, AFM was used. As reported in ESI $\dagger$ Fig. S6, WT $A \beta 42$ and $A \beta 42 \cdot C B[8]$ samples presented both fibrils (several hundred $\mathrm{nm}$ in length and approximately $1 \mathrm{~nm}$ in height) and longer fibres ( $>1 \mu \mathrm{m}$ in length). The main difference recorded was in the height of the fibres: $2.0 \mathrm{~nm}$ maximum for $\mathrm{A} \beta 42 \cdot \mathrm{CB}[8]$ fibres, whereas WT Aß42 fibres showed a height around $4 \mathrm{~nm}$. The observed difference in height supports a similar protofibrillar structure to that of the WT, but with a different assembly of the protofibrils into mature fibres. ${ }^{5,52,53}$

In order to evaluate the increase in size of the aggregates, their hydrodynamic radius was measured by DLS, as reported in Fig. S7 (ESI $\dagger$ ). The data were collected over time to closely follow the change in dimension of the complexes. A $\beta 42$ alone showed a polydisperse population, with some small particles $(12 \mathrm{~nm})$ and larger aggregates $(80 \mathrm{~nm})$ from the first measurement; an increase in size over $6 \mathrm{~h}$ up to $700 \mathrm{~nm}$ in diameter was observed (see Fig. S7a, ESI $\dagger$ ). Samples containing $\mathrm{CB}[8]$ were also polydisperse, but the size of the aggregates appeared to be larger than $\mathrm{A} \beta 42$ alone; in the presence of a 6 -fold excess of $\mathrm{CB}[8]$ the major populations upon dissolution (time $=0 \mathrm{~h}$ ) were already 21.5 and $380 \mathrm{~nm}$ (see Fig. S7c, ESI $\dagger$ ). The size of the aggregates in the $\mathrm{A} \beta 42 \cdot \mathrm{CB}[8]$ samples increased more rapidly than in the samples without $\mathrm{CB}[8]$ and the final distribution after $6 \mathrm{~h}$ showed high polydispersity with larger aggregates ranging from 600 to $1200 \mathrm{~nm}$ (see Fig. S7, ESI $\dagger$ ).
The ThT assay indicated a longer lag phase for the $\mathrm{A} \beta 42$. $\mathrm{CB}[8]$ complex than for WT $\mathrm{A} \beta 42$, but an increase in the rate of elongation. The data obtained by $\mathrm{CD}$, however, demonstrated an earlier conversion to $\beta$-sheet structure and, in conjunction with TEM and DLS data, showed a faster rate of aggregation for $\mathrm{A} \beta 42 \cdot \mathrm{CB}[8]$. The early aggregates formed in the presence of $\mathrm{CB}[8]$ can be considered on-pathway, as in the presence of WT $\mathrm{A} \beta 42$, they further assemble to form fibres that retain the major structural characteristics of the WT, while incorporating several features observed in the $\mathrm{A} \beta 42 \cdot \mathrm{CB}[8]$ system (Fig. S5b, ESI $\dagger$ ). Nevertheless, the structural differences inherent to the soluble oligomers (in the presence of $\mathrm{CB}[8]$ ) produce fibres, which are generally more cross-linked and have different heights, as reported by TEM and AFM studies, suggesting that A $\beta 42 \cdot \mathrm{CB}[8]$ aggregates pack differently into mature fibres. Considering all the data collected, it is evident that $\mathrm{CB}[8]$ enhances the aggregation rate of $\mathrm{A} \beta 42$, producing fibrillar aggregates of a larger size compared to those of the WT.

\section{$\mathrm{A} \beta-\mathrm{CB}[8]$ aggregates are less toxic and show lower cell-uptake}

In order to evaluate whether or not the structural differences between the aggregates formed by $\mathrm{A} \beta 42$ in the presence and in the absence of $\mathrm{CB}[8]$ are associated to different toxicity profiles, freshly dissolved $\mathrm{A} \beta 42$ in the presence of varying concentrations of the macrocycle was added to SH-SY5Y culture media. While WT A 442 showed an inherent toxicity after $48 \mathrm{~h}$ of incubation by MTS assay, the use of 1 equivalent of $\mathrm{CB}[8]$ significantly increased the cell viability, which reached a maximum value with only 1.5 equivalents of $\mathrm{CB}[8]$ (Fig. 4a). On account of the difference in toxicity, we employed fluorescence microscopy to image oligomer distribution within the cells. In order to have a dye directly attached to the peptide, which did not interact with the macrocycle, we prepared an used an N-terminal FITC-labelled 


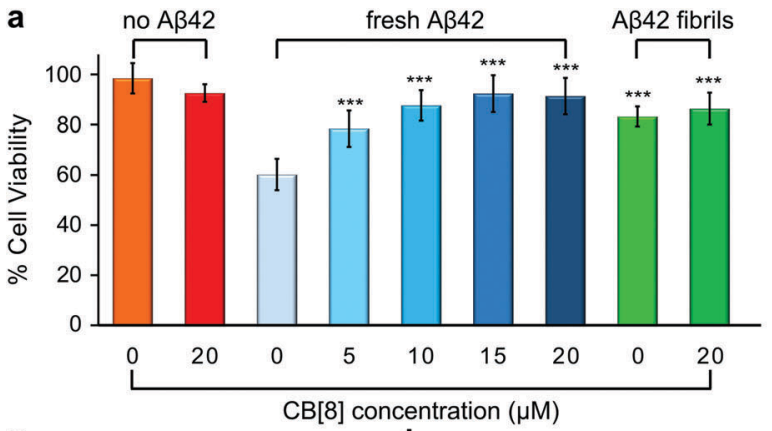

b

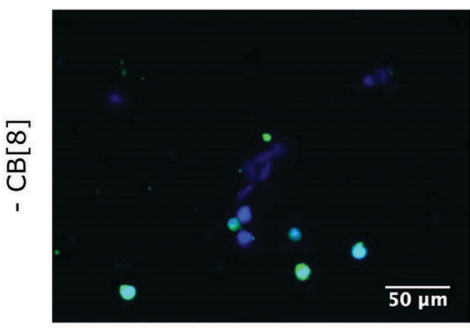

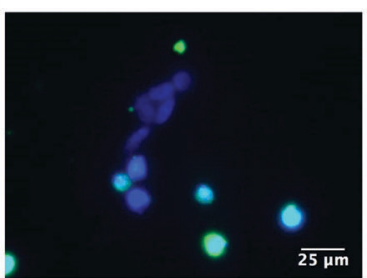

d

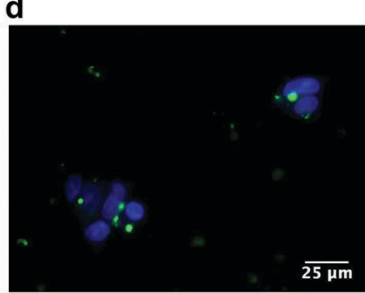

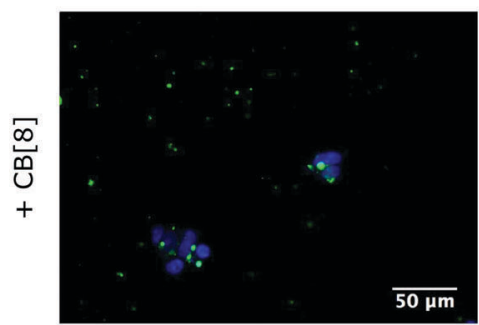

fresh $A \beta 42$
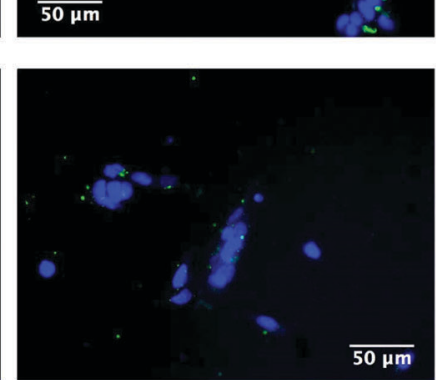

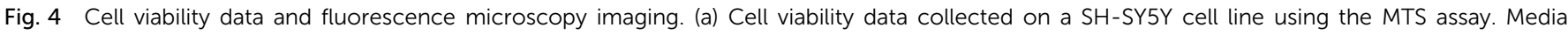

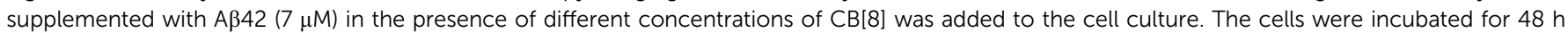

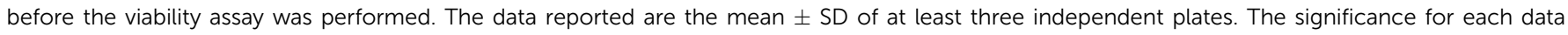

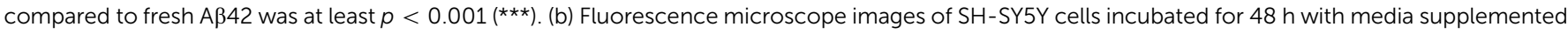

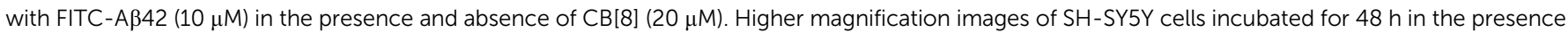

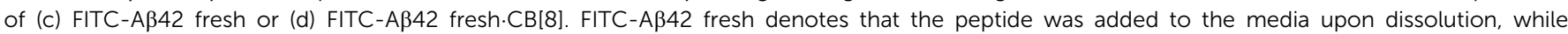

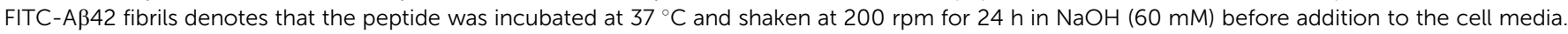

A $\beta 42$ (FITC-A $\beta 42$ ) in these experiments. As $A \beta$ oligomers interact with cell membranes, ${ }^{5}$ we expected to image fluorescence inside SH-SY5Y cells after incubation for $48 \mathrm{~h}$ in cell media containing FITC-A $\beta 42$. Bright field images (see Fig. S9, ESI $\dagger$ ) showed that the majority of SH-SY5Y cells had lost their characteristic shape becoming rounded, thus indicating cell death. Extensive FITC fluorescence was observed throughout these dead cells, as shown in Fig. $4 \mathrm{~b}$ and c, and its overlap with DAPI fluorescence demonstrated the catastrophic disruption of the nuclear envelope. The few live cells that remained after $48 \mathrm{~h}$ did not present any significant FITC fluorescence. On the contrary, when FITC-A $\beta 42$ was added to the cells in the presence of $\mathrm{CB}[8]$, the FITC emission was distributed both outside the cells and in the cytoplasm of living cells, but not in the nuclei (stained blue with DAPI) (Fig. 4b and d). Moreover, the FITC fluorescence in the cytoplasm did not appear to be homogeneously distributed, suggesting that the uptake of these supramolecular oligomers happens through a different pathway, possibly endocytosis, and their toxicity is thus substantially lower.

To assess the impact of any possible interactions between a pre-aggregated $\mathrm{A} \beta 42$ and $\mathrm{CB}[8]$ on cell viability, a peptide solution was incubated for $24 \mathrm{~h}$ at $37{ }^{\circ} \mathrm{C}$ to provide fibrils, which were then added to SH-SY5Y culture media with and without the macrocycle. Although the data obtained by MTS assay showed a higher cell viability than fresh WT A $\beta 42$, the values in the presence and in the absence of $\mathrm{CB}[8]$ were indistinguishable ( $p>0.05$, Fig. 4a). Nevertheless, they suggested that either $\mathrm{CB}[8]$ is unable to interact with pre-aggregated $\mathrm{A} \beta 42$ fibrils, or the species formed by fibrillar $\mathrm{A} \beta 42$ and $\mathrm{CB}[8]$ do not exhibit a significant toxicity. The cell uptake behavior of the fibrillar FITC-A $\beta 42$ was the same irrespective of the presence of $\mathrm{CB}[8]$, but differed from the fresh FITC-A $\beta 42$ uptake; however, these fibrils mirrored the uptake observed for fresh FITC-A $\beta 42$ when incubated with the cells in the presence of $\mathrm{CB}[8]$ (Fig. 4b). These results suggested that the faster aggregation induced by $\mathrm{CB}[8]$ is indeed directly correlated with a lower in vitro toxicity.

\section{Conclusion}

One of the major challenges hindering a detailed understanding of the $\mathrm{A} \beta$ toxicity mechanism is to define its toxic structure on account of the peptide's ability to constantly change conformation in a fast equilibrium among different oligomers. Most of the studies in the literature have been focusing on the complete inhibition of the aggregation of $A \beta,{ }^{1,5}$ while only a few have suggested increased aggregation as a possibility for toxicity reduction. ${ }^{15-17}$ Recently, the inhibition of one specific aggregation pathway that impedes oligomer production, yet does not prevent fiber formation, has been reported ${ }^{14}$.

In the present study we employed the macrocycle $\mathrm{CB}[8]$ to simultaneously complex aromatic residues from adjacent strands of $\mathrm{A} \beta 42$ to modify the aggregation propensity of the sequence (Fig. 5). The aggregates formed are able to surpass the oligomeric toxic stage ensuring higher cell viability. $\mathrm{CB}[8]$ clearly demonstrated preferential binding to the Phe residues and, most likely, to $\mathrm{Tyr}_{10}$ as well, thus altering the solvent exposure of these residues. The aggregates formed by $\mathrm{A} \beta 42$ and $\mathrm{CB}[8]$ enhanced ThT fluorescence, confirming the formation of hydrophobic pockets, and they also exhibited $\beta$-sheet formation by CD at a 


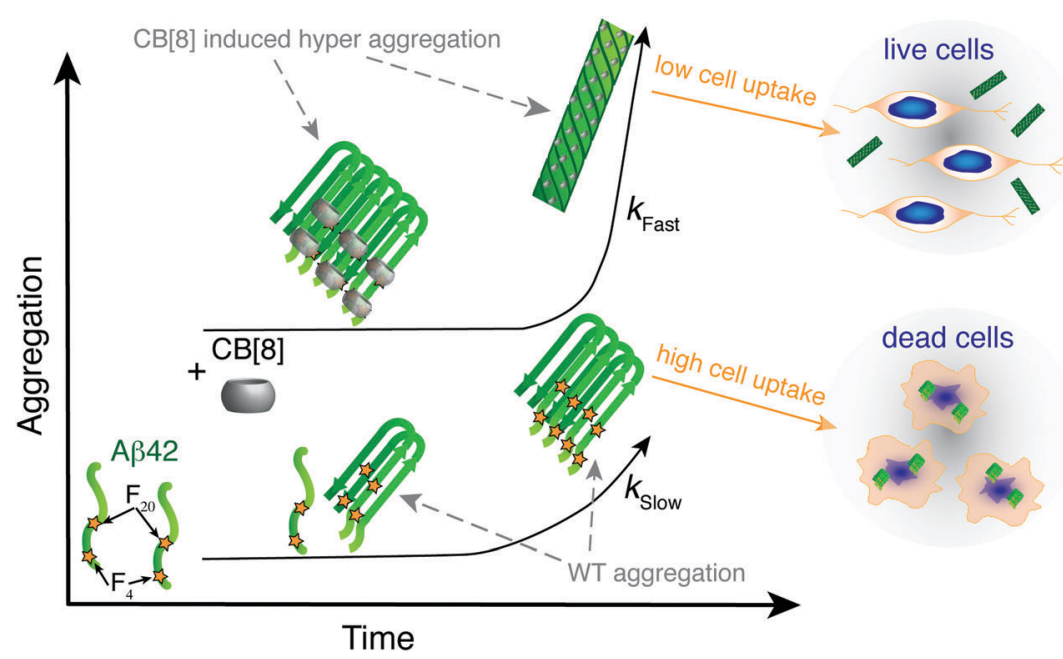

Fig. $5 \mathrm{CB}[8]$ modifies exposure of hydrophobic residues and aggregation rate, thus reducing $A \beta 42$ toxicity. Schematic representing the aggregation of $\mathrm{A} \beta 42$ over time in the presence and in the absence of $\mathrm{CB}[8]$. When the macrocycle is added to $A \beta 42$, the hydrophobic residues are shielded and the aggregates grow faster and are larger, thus reducing $A \beta 42$ cell uptake and toxicity.

very early stage of aggregation $(<1 \mathrm{~h})$. Importantly, the CD bands obtained from the supramolecular assemblies showed a red shift compared to WT A $\beta 42$, indicating a denser packing of Phe residues, complexed within the $\mathrm{CB}[8]$ cavity. ${ }^{42-44}$ Additionally, ThT, CD, TEM and DLS data suggested that $\mathrm{CB}[8]$ was able to significantly increase the rate of $\mathrm{A} \beta 42$ aggregation, which is in agreement with our theory (Fig. 5).

Most importantly, $\mathrm{A} \beta 42$ showed a lower toxicity in a neuronal cell line in the presence of $\mathrm{CB}[8]$. Moreover, fluorescence imaging showed a lower cell uptake of $A \beta 42$ administered in conjunction with $\mathrm{CB}[8]$ than in its absence. These results might be related to several factors, such as a different interaction with the cell membrane in the presence of the macrocycle, but are clearly related to an increased rate of aggregation that enables the formation of larger aggregates in a shorter period of time, which appear to be less prone to cell uptake.

The use of a supramolecular host, the macrocycle $\mathrm{CB}[8]$, decreases the in vitro toxicity of $\mathrm{A} \beta 42$ by increasing its rate of aggregation, in contrast to the inhibition-mediated approach commonly adopted. Our findings pave the way for alternative routes to counteract Alzheimer's disease, exploiting supramolecular chemistry.

\section{Conflict of interest}

The authors declare no competing financial interest.

\section{Acknowledgements}

The authors are grateful for funding from an ERC Starting Investigator grant ASPiRe (No. 240629) and an EPSRC Programme grant SNaP (EP/G060649/1). The authors are also grateful to Prof. T. J. Knowles for helpful discussions and Dr Ji Liu for support with the cell culture experiments, Matthew J. Rowland for supplying $\mathrm{CB}[8]$ and Giulia Guidetti for helping with AFM experiments.

\section{References}

1 A. Rauk, Chem. Soc. Rev., 2009, 2698-2715.

2 C. Haass and D. J. Selkoe, Nat. Rev. Mol. Cell Biol., 2007, 8, 101-112.

3 M. Shoji, T. Golde, J. Ghiso, T. Cheung, S. Estus, L. Shaffer, X. Cai, D. McKay, R. Tintner and B. Frangione, Science, 1992, 258, 126-129.

4 M. Ahmed, J. Davis, D. Aucoin, T. Sato, S. Ahuja, S. Aimoto, J. I. Elliott, W. E. Van Nostrand and S. O. Smith, Nat. Struct. Mol. Biol., 2010, 17, 561-567.

5 D. Eisenberg and M. Jucker, Cell, 2012, 148, 1188-1203.

6 T. Lührs, C. Ritter, M. Adrian, D. Riek-Loher, B. Bohrmann, H. Döbeli, D. Schubert and R. Riek, Proc. Natl. Acad. Sci. U. S. A., 2005, 102, 17342-17347.

7 G. Bitan, A. Lomakin and D. B. Teplow, J. Biol. Chem., 2001, 276, 35176-35184.

8 G. M. Shankar, S. Li, T. H. Mehta, A. Garcia-Munoz, N. E. Shepardson, I. Smith, F. M. Brett, M. A. Farrell, M. J. Rowan, C. A. Lemere, C. M. Regan, D. M. Walsh, B. L. Sabatini and D. J. Selkoe, Nat. Med., 2008, 14, 837-842.

9 K. Ono, M. M. Condron and D. B. Teplow, Proc. Natl. Acad. Sci. U. S. A., 2009, 106, 14745-14750.

10 S. L. Bernstein, N. F. Dupuis, N. D. Lazo, T. Wyttenbach, M. M. Condron, G. Bitan, D. B. Teplow, J. Shea, B. T. Ruotolo, C. V. Robinson and M. T. Bowers, Nat. Chem., 2009, 1, 326-331.

11 S. Lesné, M. T. Koh, L. Kotilinek, R. Kayed, C. G. Glabe, A. Yang, M. Gallagher and K. H. Ashe, Nature, 2006, 440, 352-357.

12 M. P. Lambert, A. K. Barlow, B. A. Chromy, C. Edwards, R. Freed, M. Liosatos, T. E. Morgan, I. Rozovsky, B. Trommer, K. L. Viola, P. Wals, C. Zhang, C. E. Finch, G. A. Krafft and W. L. Klein, Proc. Natl. Acad. Sci. U. S. A., 1998, 95, 6448-6453.

13 B. Keshet, I. H. Yang and T. A. Good, Biotechnol. Bioeng., 2010, 106, 333-337.

14 S. I. A. Cohen, P. Arosio, J. Presto, F. R. Kurudenkandy, H. Biverstoal, L. Dolfe, C. Dunning, X. Yang, B. Frohm, 
M. Vendruscolo, J. Johansson, C. M. Dobson, A. Fisahn, T. P. J. Knowles and S. Linse, Nat. Struct. Mol. Biol., 2015, 22, 207-213.

15 J. Bieschke, M. Herbst, T. Wiglenda, R. P. Friedrich, A. Boeddrich, F. Schiele, D. Kleckers, J. M. Lopez del Amo, B. A. Grüning, Q. Wang, M. R. Schmidt, R. Lurz, R. Anwyl, S. Schnoegl, M. Fåndrich, R. F. Frank, B. Reif, S. Günther, D. M. Walsh and E. E. Wanker, Nat. Chem. Biol., 2012, 8, 93-101.

16 L. Civitelli, L. Sandin, E. Nelson, S. I. Khattak, A.-C. Brorsson and K. Kågedal, J. Biol. Chem., 2016, 291, 9233-9243.

17 E. Prade, C. Barucker, R. Sarkar, G. Althoff-Ospelt, J. M. L. del Amo, S. Hossain, Y. Zhong, G. Multhaup and B. Reif, Biochemistry, 2016, 55, 1839-1849.

18 O. Klementieva, N. Benseny-Cases, A. Gella, D. Appelhans, B. Voit and J. Cladera, Biomacromolecules, 2011, 12, 3903-3909.

19 V. D. Uzunova, C. Cullinan, K. Brix, W. M. Nau and A. I. Day, Org. Biomol. Chem., 2010, 8, 2037-2042.

20 G. Hettiarachchi, D. Nguyen, J. Wu, D. Lucas, D. Ma, L. Isaacs and V. Briken, PLoS One, 2010, 5, 1-10.

21 L. M. Heitmann, A. B. Taylor, P. J. Hart and A. R. Urbach, J. Am. Chem. Soc., 2006, 38, 12574-12581.

22 P. Rajgariah and A. Urbach, J. Inclusion Phenom. Macrocyclic Chem., 2008, 62, 251-254.

23 H. D. Nguyen, D. T. Dang, J. L. J. van Dongen and L. Brunsveld, Angew. Chem., Int. Ed., 2010, 49, 895-898.

24 S. Sonzini, S. T. J. Ryan and O. A. Scherman, Chem. Commun., 2013, 49, 8779-8781.

25 L. C. Smith, D. G. Leach, B. E. Blaylock, O. A. Ali and A. R. Urbach, J. Am. Chem. Soc., 2015, 137, 3663-3669.

26 S. J. Barrow, S. Kasera, M. J. Rowland, J. del Barrio and O. A. Scherman, Chem. Rev., 2015, 115, 12320-12406.

27 R. J. Gubeli, S. Sonzini, A. Podmore, P. Ravn, O. A. Scherman and C. F. van der Walle, Chem. Commun., 2016, 52, 4235-4238.

28 J. M. Chinai, A. B. Taylor, L. M. Ryno, N. D. Hargreaves, C. A. Morris, P. J. Hart and A. R. Urbach, J. Am. Chem. Soc., 2011, 133, 8810-8813.

29 H. H. Lee, T. S. Choi, S. J. C. Lee, J. W. Lee, J. Park, Y. H. Ko, W. J. Kim, K. Kim and H. I. Kim, Angew. Chem., Int. Ed., 2014, 53, 7461-7465.

30 S. Sankaran, M. C. Kiren and P. Jonkheijm, ACS Nano, 2015, 9, 3579-3586.

31 B. Bacsa, S. Bësze and C. O. Kappe, J. Org. Chem., 2010, 75, 2103-2106.

32 H. Huang and D. Rabenstein, J. Pept. Res., 1999, 53, 548-553.
33 J. Lee, E. K. Culyba, E. T. Powers and J. W. Kelly, Nat. Chem. Biol., 2011, 7, 602-609.

34 H. Gruppen, J. Agric. Food Chem., 2007, 55, 5445-5451.

35 L. Nielsen, R. Khurana, A. Coats, S. Frokjaer, J. Brange, S. Vyas, V. N. Uversky and A. L. Fink, Biochemistry, 2001, 40, 6036-6046.

36 S. Yi and A. E. Kaifer, J. Org. Chem., 2011, 76, 10275-10278.

37 K. Murphy, P. Privalov and S. Gill, Science, 1990, 247, 559-561.

38 R. L. Baldwin, Proc. Natl. Acad. Sci. U. S. A., 1986, 8069-8072.

39 P. L. Privalov and G. I. Makhatadze, J. Mol. Biol., 1993, 232, 660-679.

40 A. C. Bhasikuttan, S. Dutta-Choudhury, H. Pal and J. Mohanty, Isr. J. Chem., 2011, 51, 634-645.

41 S. Dutta Choudhury, J. Mohanty, H. P. Upadhyaya, A. C. Bhasikuttan and H. Pal, J. Phys. Chem. B, 2009, 113, 1891-1898.

42 I. W. Hamley, D. R. Nutt, G. D. Brown, J. F. Miravet, B. Escuder and F. Rodriguez-Llansola, J. Phys. Chem. B, 2010, 114, 940-951.

43 V. Castelletto, I. Hamley and P. Harris, Biophys. Chem., 2008, 138, 29-35.

44 S. Dehn, V. Castelletto, I. W. Hamley and S. Perrier, Biomacromolecules, 2012, 13, 2739-2747.

45 B. C. Pemberton, N. Barooah, D. K. Srivatsava and J. Sivaguru, Chem. Commun., 2010, 46, 225-227.

46 M. Pattabiraman, S. Lakshmi, A. Kaanumalle and V. Ramamurthy, Langmuir, 2006, 22, 7605-7609.

47 Y. Lan, Y. Wu, A. Karas and O. A. Scherman, Angew. Chem., Int. Ed., 2014, 53, 2166-2169.

48 C. Yang, T. Mori, Y. Origane, Y. H. Ko, N. Selvapalam, K. Kim and Y. Inoue, J. Am. Chem. Soc., 2008, 130, 8574-8575.

49 N. Barooah, B. C. Pemberton and J. Sivaguru, Org. Lett., 2008, 10, 3339-3342.

50 A. T. Petkova, R. D. Leapman, Z. Guo, W.-M. Yau, M. P. Mattson and R. Tycko, Science, 2005, 307, 262-265.

51 Y. Xiao, B. Ma, D. McElheny, S. Parthasarathy, F. Long, M. Hoshi, R. Nussinov and Y. Ishii, Nat. Struct. Mol. Biol., 2015, 22, 499-505.

52 A. K. Paravastu, R. D. Lepman, W.-M. Yau and R. Tycko, Proc. Natl. Acad. Sci. U. S. A., 2008, 105, 18349-18354.

53 A. W. P. Fitzpatrick, G. T. Debelouchina, M. J. Bayro, D. K. Clare, M. A. Caporini, V. S. Bajaj, C. P. Jaroniec, L. Wang, V. Ladizhansky, S. A. Müller, C. E. MacPhee, C. A. Waudby, H. R. Mott, A. De Simone, T. P. J. Knowles, H. R. Saibil, M. Vendruscolo, E. V. Orlova, R. G. Griffin and C. M. Dobson, Proc. Natl. Acad. Sci. U. S. A., 2013, 110, 5468-5473. 